\title{
A Short Note on Accent-bias, Social Identity and Ethnocentrism
}

\author{
Rahul Chakraborty* \\ Department of Communication Disorders, Texas State University, USA
}

Corresponding Author: Rahul Chakraborty, E-mail: rc39@txstate.edu

\begin{tabular}{l} 
ARTICLE INFO \\
\hline Article history \\
Received: May 18, 2017 \\
Accepted: July 23, 2017 \\
Published: August 31, 2017 \\
Volume: 8 Issue: 4 \\
Advance access: August 2017 \\
\hline Conflicts of interest: None \\
Funding: None \\
\hline
\end{tabular}

Key words:

Social Identity,

Ethnocentrism,

Accent,

Biases,

Discrimination

\begin{abstract}
This paper discusses the interrelations among accent-based biases, social identity and ethnocentrism. Construction of social identity creates a set of ethnocentric values within a person, which indirectly or directly plays a pivotal role in generating accent related biases. Starting with Tajfel's (1959) social identity theory and then the discussion of ethnocentrism, accent related biases have a long documented origin, development and consequences. People construct their social identity based on numerous variables and then their in-group and out-group memberships are established. Ethnocentrism, as a variable, influences listeners' accent perception and subsequent judgment regarding their perceived accent. The degree of ethnocentrism is related to speakers' potential accent biases. As legal safeguard against accent related biases is absent, active resistance and awareness-initiation are expected from speech language pathologists and the concerned community in general. Role of training institutions is discussed.
\end{abstract}

\section{INTRODUCTION}

Speakers' accents is usually considered an "honest signal" of group membership in human evolutionary history (Cohen, 2012). In the US, speakers with nonnative accent are experiencing fewer employment opportunities, differential employee compensation, lesser housing options, impoverished health care service, lower credibility and discriminatory responses in the courts (Ovalle and Chakraborty, 2013; Deprez-Sims \& Morris, 2013; Deprez-Sims \& Morris, 2010; Gluszek \& Dovidio, 2010). Between 1996 and 2000, complaints of accent based unfair hiring and firing practices submitted to the U.S. Equal Employment Opportunity Commission has jumped from 77 to 400 (Newman, 2002) even though globalization is expected to improve multicultural sensitivity. In contrast to racial, ethnic, or sex discrimination, listeners have considerable latitude when discriminating against people with nonnative accents (Lippi-Green, 1997).

Even though social science has documented and criticized the widely prevalent accent-based biases and its consequences as stereotype formation, prejudice and discrimination, the field of Speech Language Pathology has offered a cursory attention to the issue of accent related biases. When numerous social science studies have reported unfavorable evaluations of nonnative accent, very few studies clinically explored and focused on the prevention of ac- cent based discrimination (Gluszek \& Dovidio, 2010; Giles, 1971; Neuliep \& Speten-Hansen, 2013). Instead, accent-reduction and accent-modification businesses have flourished extensively (Gluszek \& Dovidio, 2010; Montgomery, 1999; Shah, 2012). Regardless of discipline-specific focus on content areas in accent and its consequences, it is widely accepted that the primary reason behind biases is self-constructed social identity and high ethnocentric attitude (Neuliep \& Speten-Hansen, 2013; Giles, 1971).

Socially, due to growing language contacts among speakers of English from variable L1 backgrounds, nonnative accent is a global phenomenon and so is its consequence. A sensible appreciation of potential social, academic and economic consequences of speaking with a nonnative accent, and how listeners construct stereotype and stigma, might eventually help minimize adverse consequences of nonnative accent. Hence, in the field of speech language pathology, it is critical to engage in formal discussion on accent discrimination because when individuals are unaware of their own biases, they are more likely to perpetuate their negative (e.g., low intelligence level, lack of honesty) perception towards speaker with nonnative accent (Perry, Murphy, \& Dovidio, 2015). The American Speech and Hearing Association (ASHA) overseeing the field of speech language pathology has been relentlessly trying to educate speech language pathologist to promote multicultural sensitivity and 
minimize potential biases towards nonnative speech and language behaviors. In this note, we review the concepts of social identity and ethnocentrism, and present how these constructs are surfaced through accent related biases, prejudice and discrimination.

\section{Social Identity}

Social identity is an individual's awareness of valuable membership in certain social groups (Tajfel, 1959, 1972, 1974). A social group is constructed when more than two people who identify, define, and evaluate themselves similarly (Hogg et al., 2004; Hogg, 2006). The social groups always compete against each other for stature and prestige (Tajfel, 1972, 1974). Members of the same social groups relate to, compete with, and differentiate themselves from nonmembers; that is, outgroups (Hogg et al., 2004; Hogg, 2006); thus in-group versus outgroup comparison mediated tension, conflict or discrimination is formed. Based on an individual's perceived commonality with other group members, one might have several group-membership.

The theorization of social identity was introduced by Henri Tajfel (1959) and was exegesised further (Hogg et al., 2004; Hogg, 2006; Hogg \& Abrams, 1988; Rubin \& Hewstone, 1998; Tajfel, 1969, 1972, 1974; Tajfel \& Turner, 1979). Now it is known as the Social Identity Theory (SIT).

The SIT has social categorization as its principal construct. According to Hogg $(2004,2006)$, social categorization is a cognitive process to represent groups in terms of prototypes and using prototypes people categorize others by evaluating them according to their group memberships rather than as individuals. Inherently, any prototypical concept is construed upon an imprecise sets of interrelated characteristics mediated through human perceptions, attitudes, and behaviors (Hogg, 2004, 2006). When prototypical group identities are constructed, simultaneously and continuously in-group homophily and outgroup heterophily are evaluated and interpreted (Hogg et al., 2004; Hogg, 2006; Hogg and Abrams, 1988; Rubin and Hewstone, 1998; Tajfel, 1972; Tajfel and Turner, 1979). That is, using social categorization, members of a social group not only identifies what features define their current group membership and/or characteristics of their group, but also help distinguish from other social groups; thus, social categorization maximizes in-group similarities and outgroup differences (Neuliep \& Speten-Hansen, 2013). The primary focus of Tajfel's SIT was to explain the consequence of group membership on prejudice, discrimination, and group conflict (Hogg et al., 2004). It has been reported that the degree of in-group identification creates ingroup bias, outgroup derogation, and outgroup discrimination (Gagnon \& Bourhis, 1996; Perreault and Bourhis, 1999). Thus, outgroup discrimination is directly related to ingroup identification (Gagnon \& Bourhis, 1996; Perreault \& Bourhis, 1999). That is, individuals with strong ingroup identification exhibit strong outgroup discrimination whereas those individuals who identified weakly with their ingroup did not discriminate against the outgroup (Gagnon and Bourhis, 1996).

Social Identity Theory (SIT) offers an augmenting explanation of listeners' perception of nonnative accents during intergroup and intragroup interaction. SIT also attempts to explain why we typically observe some negative perception of speakers with nonnative accent (i.e., outgroups). However, why some individuals acquire and exhibit strong ingroup identification while others do not, has been answered in studies that have looked into intrapersonal variables or individual differences. One such intrapersonal variable that promotes high ingroup indentification and outgroup discrimination is ethnocentrism (Perreault \& Bourhis, 1999); ethnocentric persons evaluated their ingroups favorably while simultaneously stigmatizing outgroups (Berry et al., 1977).

\section{Ethnocentrism}

The term ethnocentrism and its fundamental concept was introduced in social science by Sumner (1906). It was defined as "the technical name for this view of things in which one's own group is the center of everything, and all others are scaled and rated with reference to it" (p. 13). Initially it was interpreted as a psychological construct differentiating between two groups: in-groups (i.e., the group with which an individual identifies) and out-groups (i.e., the group with which an individual does not identify or anything other than in-groups). Currently, ethnocentrism is a more holistic term infusing individual, social and cultural nuances; incorporating the social aspect of human psychological reality. Hence, now it is considered to be a psycho-sociological concept.

Extension of Tajfel's (1972) SIT's concept of in-group affinity and the past 50-60 years of social science research have witnessed considerable discussion on the nature and prevalence of ethnocentrism. Across the board, the consensus is - an ethnocentric person harbors resilient affinity and favoritism in their attitudes and behaviors toward in groups, often at the expense of the outgroup (Hewstone \& Ward, 1985; Islam \& Hewstone, 1993; Weber, 1994). Historically, the highly ethnocentric nature of human species with their resilient propensity to consider their own way as the only reference point, has led to almost psychopathological forms of ethnocentrism surfaced in discrimination, prejudice, and even ethnic cleansing (Hansen, Rakić, Steffens \& Weise, 2017). Deviations from that self-constructed or socially-constructed reference point (s) are usually viewed unfavorably by ethnocentric people and will be reactively considered inferior or aberration, which might also include people with different languages or accents. Highly ethnocentric people would prefer in-group interaction and avoid interaction with representatives of other cultural groups or out-groups as they harbor negative perceptions of them (Neuliep et al., 2001; Gudykunst \& Kim, 2004; Neuliep \& Ryan, 1998). Ethnocentrism leads to ingroup identification, which leads to ingroup-bias and consequently we observe outgroup derogation, and discrimination (Gagnon and Bourhis, 1996).

Ethnocentric bias is not domain specific; it is pervasive. For example, the influence of ethnocentrism is observed even in manager-subordinate communication (Neuliep et al., 2005). For example, ethnocentrism was negatively correlated with social perceptions of the manager when an Asian student manager reprimanded a White student worker. But, in that study, ethnocentrism was not correlated with social 
perception when a White student manager reprimanded the same White student worker. In another study with regional varieties of English, revealed that the participating British students who scored high on the British Ethnocentrism scale (Warr et al., 1967) rated the accented speakers less favorably than those students scoring low on the scale (Giles, 1971); students who had higher ethnocentric ratings perceived the prestigious Southern Standard accent more favorably than the students who had lower ratings on the ethnocentric scale. Thus, when SIT and ethnocentrism are considered together, with the empirical reports of last 50-60 years, it is probably safe to assume that higher ethnocentricity will likely allow listeners to view speakers with nonnative accents negatively. However, while on one end, ethnocentric persons see the ingroup as superior to out-groups and cooperate with in-group members while competing with outgroup members, ethnocentrism may also serve a powerful descriptive function by defining one's group identity under the threat of attack - ethnocentrism should not be always construed as a negative trait (Neuliep \& McCroskey, 1997). This very in-group affiliations probably form the basis of patriotism and unfazed courage to sacrifice for one's own group under threat. Thus numerous research reports have documented how nonnative accent is treated as an index of outgroup affiliation and as a consequence, frequently sculpted in discriminatory-negative identity construction surfaced through cognitions, affect, and behaviors toward speakers with nonnative accent.

\section{Accent Biases}

The central theme of SIT is social categorization (Hogg et al., 2004) and as we know, linguistic variation is structured around social identity, which is the primary construct of ethnocentrism (Lippi-Green, 1997). Linguistic variations between groups surfaced as accent is an effective means and manner for exclusion/discrimination because when people reject an accent, they are simultaneously rejecting speakers' identity realized through his or her race, ethnic heritage, national origin, regional affiliation, or economic class (Lippi-Green, 1997). Perception of nonnative accent and the discriminatory and inflammatory consequences thereafter are centered around the socially constructed identity of individual listeners. Group affinity based on ethnocentrism is endorsed as individuals with the same accent tend to cooperate more when presented with a common task (Heblich, Lameli \& Riener, 2015). On the other end, more competitiveness is observed when an individual is paired with someone of a different accent. It seems, the linguistic distance between two accents help form ethnocentric territories and influence listeners' attributes of speakers' accent (Heblich, Lameli \& Riener, 2015).

There is a large volume of research reports on preventing biases against people based on their skin color, ethnicity, or gender (refs). However, accent related biases appear to be more acceptable and less opposed than racial, religious or gender discrimination, even though globally accent-bias is a widely acknowledged form of discrimination, (Giles \& Watson, 2013; Ng, 2007; Hansen, Rakić, \& Steffens, 2014). For example, when participants were presented with a list of 105 potential targets of prejudice, speakers with nonnative-accent or non-standard accent were not even mentioned (Crandall, Eshleman, \& O'Brien, 2002). A note in the employment contract form usually mention that the employer is an equal opportunity provider and do not discriminate based on race, religion, color, ethnicity etc; accent is never mentioned in such contract form!

With the current trends in globalization, cross-linguistic interaction is not an exceptional sociolinguistic moment people continuously encounter variations of the prototypical standard form of a target language. Along with multicultural interaction, people might experience prejudice and discrimination based on their ethnicity, race, skin color and also based on their native language or accent (Fuertes, Gottdiener, Martin, Gilbert, \& Giles, 2012; Gluszek \& Dovidio, 2010). Even though language proficiency is a different construct compared to accent, there are numerous reports where people with nonnative accent are considered poor language users (Gluszek \& Dovidio, 2010). Frequently, speakers with nonnative accent are considered less intelligent, less loyal, less competent and of lower status and face both prejudice and stereotypes (Gluszek \& Dovidio, 2010b; Ng \& Bradac, 1993; Matsuda, 1991). Overall, accent related biases have been reported is reported not only in the sociolinguistic literature citing stereotype formation, even academic and corporate sectors have extensively reported consequences of accent related biases.

An association between accent and stereotype formation have been noticed with specific sociocultural groups (Yzerbyt, Provost, and Cornielle 2005; Giles, Williams, Mackei, Rosselli, 1995; Milroy \& McClenaghan, 1977). However, listeners' association among accent, stereotypy formation and the ethnic or national origin of an accent might not be accurate (Giles et al., 1995; Milroy and McClenaghan, 1977). For example, Belgian speakers were perceived as less competent than French speakers, but that Belgian speakers were perceived as warmer than French speakers in a study by Yzerbyt, Provost, and Cornielle (2005). Similar results were reported with credibility ratings. Based on credibility ratings assigned to speakers with different accents, speakers with standard American accents delivering false information were perceived as more trustworthy than when listeners rated the credibility of speakers with different accents delivering false information; (e.g., Vornik, 2003).

In the USA, students with standard American English (SAE) perceived speakers with foreign accents to be inferior speakers, though the speakers had high scores on objective measures of comprehensibility and speech intelligibility; students in the USA preferred courses taught by teachers who use standard American accent (Rubin \& Smith, 1990). Speech comprehensibility is the ability to interpret the meaning of messages produced by speakers without regard for accuracy of phonetic and lexical parsing(Hustad \& Beukelman, 2002) and speech intelligibility is usually defined as how well a speaker's acoustic signal can be accurately recovered by a listener (Hustad \& Cahill, 2003). When listeners heard recordings in standard American accent and that accent was held unchanged or constant with a picture of either Cauca- 
sian or Asian face, participants responded differently to the comprehensibility of the recording (Rubin, 1992). Standard accents is usually ranked significantly higher in prestige and social status (Coupland \& Bishop, 2007).

When native speakers of English at the undergrad program in the USA were presented different variations of English from across the globe, including Australia, Canada, China, England, France, Germany, India, Ireland, Italy, Jamaica, Japan, Mexico, Russia, and Spain, significant variability in accent rating was observed (Lindemann, 2005); English produced by speakers from Mexico and China were described as most incorrect speakers and were negatively stigmatized. However, nonnative speakers from Germany, France and Italy were considered the most correct English speakers and were least stigmatized. Geopotential and socioeconomic variables interfered with the selective positive and negative evaluation of the nonnative speakers of English in these countries; speakers from less familiar countries and from countries that are considered adversaries of the US, were rated negatively. Overall, the potential consequences of nonnative accent depends on listeners' perception of the degree or extent of speakers' phonetic variation from native-speaker accent (Munro \& Derwing, 2001). That is, not every nonnative accent is rated similarly by the native listeners, the specific variety of nonnative accent plays a role in such evaluation. Even companies prefer to hire speakers with standard American accents, highlighting concerns about intelligibility and communication as the impetus (Deprez-Sims \& Morris, 2013). However, even though it is known that nonnative accent can elicit stigmatization (Fuertes, Gottdiener, Martin, Gilbert, \& Giles, 2012), disrupt information transfer mechanism (Derwing \& Munro, 2009), and understandably interfere with the speed of content processing by the listeners (Adank, Evans, Stuart-Smith, \& Scott, 2009), it would be interesting to know, to what extent processing difficulty versus other factors influence listeners judgment on nonnative accent.

Economic consequences of nonnative accent have also been explored; speakers' accents have a significant influence on their employment, evaluations of their credibility, perception of competence, job opportunities and social status (e.g. Cargile, Maeda, Rodriguez, \& Rich, 2010; Carlson \& McHenry, 2006; Creese \& Kambere, 2003; Frumkin, 2007; Fuertes, Gottdiener, Martin, Gilbert, \& Giles, 2012; Fuertes \& Gelso, 2000; Hosoda, Nguyen, \& Stone-Romero, 2012; Lev-Ari \& Keysar, 2010). Listeners' interpersonal evaluations were significantly impacted by speakers' accent and more social attractiveness, increased job opportunities, higher social status, higher intelligence, and more trustworthiness were assigned to speakers with standard accent (Fuertes et al., 2012).

In 2010 , out of 291 million people of 5 years of age and above, $21 \%$ spoke a language other than English at home (American Community Survey report, Ryan, 2013). So there is a higher probability of finding speakers with nonnative accent today in any sector. However, during job interviews, even though employers' prejudice towards second-generation immigrants by elimination and every nonnative group was discriminated, some biasness resulted in positive em- ployment decisions for some second-generation immigrants (Krings \& Olivares, 2007). Hence, the fact that employers always claim that they indiscriminately offer an equal opportunity in their workplace and are free from cognitive biases, the data probably suggest otherwise.

\section{The Role of Training Institution in the Field of Speech Language Pathology}

None of the studies mentioned above, had collected data from an industry where speech language pathologist are employed, even though the rehabilitation industry offers clinical and/or educational services. However, as a service provider, if a clinician uses a foreign accent and there is a mismatch in accent between the client and the clinician, the situation might evoke a negative predisposition due to the nonnative accent and it is not implausible to hypothesize that the discriminatory behaviors in the speech language pathology industry will mimic other industries to some extent. Biases customers or clients develop towards accents influence customers' evaluation of the service encounter. Speech Language Pathology as a service industry is certainly not immune to such possibilities.

Currently, more emphasis is on accent-reduction (Gluszek \& Dovidio, 2010; Montgomery, 1999) and accent-modification trainings (e.g., Shah, 2012), than on the prevention of accent based discrimination. Accent modification and/or reduction focus on speakers of nonnative accent, whereas prevention of accent based discrimination attempts to modify attitude and perception of the listeners. Since communication involves interlocutors, simultaneously addressing nonnative accent from both speakers and listeners' perspectives would be more productive in the long run. This is especially critical because, compared to foreign accents in Spanish or other languages, students with nonnative accent in English were asked more often to undergo accent modification (Levy \& Crowley, 2012). ASHA is allocating substantial amount of resources to improve multicultural sensitivity, however, even among SLPs and the community in general, intolerance and arbitrary association of accent and unrelated attributes are not rare (Corona et al., 2016).

However, Levy \& Crowley (2012) offered a list of suggestions for SLP's who do not have native Spanish proficiency or phonological skills as policies and practices. The way Levy \& Crowley's (2012) suggestions were drafted, they are relevant even beyond aspiring Spanish speakers and could be applied to any SLP from any linguistic background attempting to modify their phonological accuracy for a target language. Levy \& Crowley's (2012) suggestions are mildly modified below to contextualize in the global linguistic scenario.

- If a student has been accepted into a university, offer speech intelligibility training by native speakers of the target language.

- Mobilize conversational groups and infuse students to actively participate.

- Allow students to organize overseas travel experiences or participate in study abroad or language immersion programs. 
- Offer relevant language training or accent training information available on classes.

- Allow SLP students to take classes as language electives.

- Incorporate more faculty members from diverse linguistic background to heighten students multilingual sensitivity, which might reduce their ethnolinguistic notion.

- Offer CEUs through the department, university, state level or ASHA for improving pronunciation, proficiency, and cultural competence in their nonnative language.

- Offer accent modification training for students and also for anyone who might be interested.

- Offer guidance and assist students with nonnative accent during their clinical training, (Crowley, 2007).

- Collaborate with other disciplines addressing similar linguistic issues.

- Make a list of strategies accessible to students if a student can't produce a desired phonological model.

- Use software programs to offer the desired phonological models and a target pronunciation.

- Incorporate the client's family in situations where the accent mismatch is interfering with the client but not with the family members of the client. Involvement of the family members might even be helpful for children with language impairment.

- Introduce new university programs and make newer resources available.

- $\quad$ Seek help from experts and/or from ASHA's Multicultural Issues Board. As a consequence, eventually the field with have a very diverse set of clinicians.

- Being a part of an academic program, if a student files a complain of accent based discrimination to the central body governing accreditation, the governing body as a part of its quality control can always request the respective department to come up with the rectification plan in any country. In the US, the Council on Academic Accreditation in Audiology and Speech-Language can request for evidence.

- Improve social awareness and understanding to minimize discrimination towards speakers with nonnative accent and present the impact of accented speech on perception by individuals with the different speech and language disorders serviced by SLPs.

- Devise programs and policies to ensure that the quality of service does not vary between SLPs with and without nonnative accent.

- $\quad$ Emphasize the quasi-independent relationships among accent, intelligibility, and comprehensibility, which has been documented (Derwing \& Munro, 1997), to the clients and their family members, SLPs and the community.

- Emphasize the documented evidence that even if initially nonnative accent might cause perceptual difficulty, gradual familiarity would reduce listeners' difficulty with the nonnative accent perception (Bradlow \& Bent, 2008).

- Clinicians can adopt "clear speech" where the SLPs will hyperarticulate to improve speech intelligibility (Levy et al., 2010; Rogers, DeMasi, \& Krause, 2010; Smiljanic \& Bradlow, 2008).

- Incorporate interpreters in the sessions to facilitate communication discourse (Langdon \& Cheng, 2002).

- Telepractice can facilitate overall communication, intervention and treatment efficacy in cases in which there is an accent mismatch between a client and a clinician (e.g., Goral, Levy, \& Kastl, 2010).

However, it should be acknowledged that clients with phonological inaccuracy need clinician who can offer language and dialect specific phonological models. In comparison, clients with other speech-language disorders can receive services from clinicians with phonological variations. For example, a child with phonological problem should preferably receive services from a clinician who produces the targeted phones without any nonnative influence in their accent. On the contrary, a client with dysphagia, can receive therapy from a client who has nonnative accent. Clearly, justification of SLP service by nonative clinicians would depend on specific disorder for which intervention has been expected, the clients' overall attitude towards nonnative accent and clinicians' degree of accent.

\section{CONCLUSION}

The current papers wanted to thread the relationship among construction of social identity, ethnocentrism and accent discrimination. Preventing discriminatory evaluations towards nonnative accent and its speakers could possibly be minimized if listeners also assume roles of speakers with nonnative accent. Surprisingly, very little work has been done on how experiencing one's own behavior in-turn influences their perception of others (see Kawakami et al., 2012; Phills, Kawakami, Tabi, Nadolny, \& Inzlicht, 2011, Hansen, Rakić \& Steffens, 2014). SLPs can help safeguard against accent biases by offering importance to cross-cultural interpersonal skills and minimize the negative effect of client-clinician relationship. There is no legal principles against accent biases and discrimination and absence of such ethical and inconsequential human behavior is thus dangerously unprotected.

\section{REFERENCES}

Abrams, D., \& Hogg, M. A. (1988). Comments on the motivational status of self-esteem in social identity and intergroup discrimination. European Journal of Social Psychology, 18(4), 317-334.

Adank, P., Evans, B. G., Stuart-Smith, J., \& Scott, S. K. (2009). Comprehension of familiar and unfamiliar native accents under adverse listening conditions. Journal of Experimental Psychology: Human Perception and Performance, 35(2), 520.

Berry, J. W. (1977). Multiculturalism and Ethnic Attitudes in Canada.

Bradlow, A. R., \& Bent, T. (2008). Perceptual adaptation to non-native speech. Cognition, 106(2), 707-729.

Cargile, A. C., Maeda, E., Rodriguez, J., \& Rich, M. (2010). "Oh, you speak English so well!" US American listeners' perceptions of" Foreignness" among nonnative 
speakers. Journal of Asian American Studies, 13(1), 59-79.

Carlson, H. K., \& McHenry, M. A. (2006). Effect of accent and dialect on employability. Journal of employment counseling, 43(2), 70-83.

Cohen, E., Atkinson, Q. D., Dediu, D., Dingemanse, M., D. Kinzler, K., Ladd, D. R., \& Cohen, E. (2012). The evolution of tag-based cooperation in humans: the case for accent. Current Anthropology, 53(5), 588-616.

Coupland, N., \& Bishop, H. (2007). Ideologised values for British accents. Journal of sociolinguistics, 11(1), 74-93.

Crandall, C. S., Eshleman, A., \& O’brien, L. (2002). Social norms and the expression and suppression of prejudice: the struggle for internalization. Journal of personality and social psychology, 82(3), 359-378.

Creese, G., \& Kambere, E. N. (2003). What colour is your English?. Canadian Review of Sociology/Revue canadienne de sociologie, 40(5), 565-573.

Deprez-Sims, A. S., \& Morris, S. B. (2010). Accents in the workplace: Their effects during a job interview. International Journal of Psychology, 45(6), 417-426.

Deprez-Sims, A. S., \& Morris, S. B. (2013). The Effect of Non-native Accents on the Evaluation of Applicants during an Employment Interview: The development of a path model. International Journal of Selection and Assessment, 21(4), 355-367.

Derwing, T. M., \& Munro, M. J. (1997). Accent, intelligibility, and comprehensibility. Studies in second language acquisition, 19(1), 1-16.

Derwing, T. M., \& Munro, M. J. (2009). Putting accent in its place: Rethinking obstacles to communication. Language teaching, 42(4), 476-490.

Derwing, T., \& Munro, M. J. (2001). What speaking rates do non-native listeners prefer?. Applied Linguistics, 22(3), 324-337.

Frumkin, L. (2007). Influences of accent and ethnic background on perceptions of eyewitness testimony. Psychology, Crime \& Law, 13(3), 317-331.

Fuertes, J. N., \& Gelso, C. J. (2000). Hispanic counselors' race and accent and Euro Americans' universal-diverse orientation: A study of initial perceptions. Cultural Diversity and Ethnic Minority Psychology, 6(2), 211-219.

Fuertes, J. N., Gottdiener, W. H., Martin, H., Gilbert, T. C., \& Giles, H. (2012). A meta analysis of the effects of speakers' accents on interpersonal evaluations. European Journal of Social Psychology, 42(1), 120-133.

Gagnon, A., \& Bourhis, R. Y. (1996). Discrimination in the minimal group paradigm: Social identity or self-interest? Personality and Social Psychology Bulletin, 22(12), 1289-1301.

Giles, H. (1971). Ethnocentrism and the evaluation of accented speech. British Journal of Social and Clinical Psychology, 10(2), 187-188.

Giles, H., \& Watson, B. M. (2013). The social meanings of language, dialect and accent: International perspectives on speech styles (Vol. 16). Peter Lang Publishing.

Giles, H., Williams, A., Mackei, D.M., Rosselli, F., 1995. Reactions to Anglo- and Hispanic-American-ac- cented speakers: affect, identity, persuasion, and the English only controversy. Language \& Communication 165, 107-120. http://dx.doi.org/10.1016/02715309(94)00019-9.

Gluszek, A., \& Dovidio, J. F. (2010). Speaking with a nonnative accent: Perceptions of bias, communication difficulties, and belonging in the United States. Journal of Language and Social Psychology, 29(2), 224-234.

Goral, M., Levy, E. S., \& Kastl, R. (2010). Cross language treatment generalisation: A case of trilingual aphasia. Aphasiology, 24(2), 170-187.

Hansen, K., Rakić, T., \& Steffens, M. C. (2014). When actions speak louder than words: Preventing discrimination of nonstandard speakers. Journal of Language and Social Psychology, 33(1), 68-77.

Hansen, K., Steffens, M. C., Rakić, T., \& Wiese, H. (2017). When appearance does not match accent: neural correlates of ethnicity-related expectancy violations. Social Cognitive and Affective Neuroscience. 12(3), 507-515.

Heblich, S., Lameli, A., \& Riener, G. (2015). The Effect of Perceived Regional Accents on Individual Economic Behavior: A Lab Experiment on Linguistic Performance, Cognitive Ratings and Economic Decisions. PLoS ONE, 10(2), [e0113475]. DOI: 10.1371/journal. pone. 0113475 .

Hewstone, M. and Ward, C. 1985. Ethnocentrism and causal attribution in Southeast Asia. Journal of Personality and Social Psychology, 48: 614-623.

Hogg, M. A., Abrams, D., Otten, S., \& Hinkle, S. (2004). The social identity perspective intergroup relations, self-conception, and small groups. Small group research, 35(3), 246-276.

Hosoda, M., Nguyen, L. T., \& Stone-Romero, E. F. (2012). The effect of Hispanic accents on employment decisions. Journal of Managerial Psychology, 27(4), 347-364.

Hustad, K. C., \& Cahill, M. A. (2003). Effects of presentation mode and repeated familiarization on intelligibility of dysarthric speech. American Journal of Speech-Language Pathology, 12(2), 198-208.

Hustad, K. C., \& Beukelman, D. R. (2002). Listener Comprehension of Severely Dysarthric SpeechEffects of Linguistic Cues and Stimulus Cohesion. Journal of Speech, Language, and Hearing Research, 45(3), 545-558.

Islam, M. R. and Hewstone, M. 1993. Intergroup attributions and affective consequences in majority and minority groups. Journal of Personality and Social Psychology, 64: 936-950.

Kawakami, K., Phills, C. E., Greenwald, A. G., Simard, D., Pontiero, J., Brnjas, A., \& Dovidio, J. F. (2012). In perfect harmony: synchronizing the self to activated social categories. Journal of personality and social psychology, 102(3), 562-575.

Krings, F., \& Olivares, J. (2007). At the doorstep to employment: Discrimination against immigrants as a function of applicant ethnicity, job type, and raters' prejudice. International Journal of Psychology, 42(6), 406-417. 
Langdon, H. W., \& Cheng, L. R. L. (2002). Collaborating with interpreters and translators: A guide for communication disorders professionals. Eau Claire, WI: Thinking Publications.

Lindemann, S. (2005). Who speaks “broken English”? US undergraduates' perceptions of non native English. International Journal of Applied Linguistics, 15(2), 187-212.

Lippi-Green, R. (1997). English with an accent: Language, ideology, and discrimination in the United States. Psychology Press.

Lev-Ari, S., \& Keysar, B. (2010). Why don't we believe non-native speakers? The influence of accent on credibility. Journal of Experimental Social Psychology, 46(6), 1093-1096.

Levy, E. S., \& Crowley, C. J. (2012). Policies and practices regarding students with accents in speech-language pathology training programs. Communication Disorders Quarterly, 34(1), 59-68.

Matsuda, M. J. (1991). Voices of America: Accent, antidiscrimination law, and a jurisprudence for the last reconstruction. Yale Law Journal, 100(5), 1329-1407.

Milroy, L., \& McClenaghan, P. (1977). Stereotyped reactions to four educated accents in Ulster. Belfast Working Papers in Language and Linguistics, 2, 1-11.

Montgomery, J. K. (1999). Accents and Dialects: Creating a National Professional Statement. Topics in Language Disorders, 19(4), 78 -86.

Neuliep, J. W., \& Speten-Hansen, K. M. (2013). The influence of ethnocentrism on social perceptions of nonnative accents. Language \& Communication, 33(3), 167-176.

Neuliep, J. W., Hintz, S. M., \& McCroskey, J. C. (2005). The influence of ethnocentrism in organizational contexts: Perceptions of interviewee and managerial attractiveness, credibility, and effectiveness. Communication Quarterly, 53(1), 41-56.

Neuliep, J. W., \& Ryan, D. J. (1998). The influence of intercultural communication apprehension and socio communicative orientation on uncertainty reduction during initial cross- cultural interaction. Communication Quarterly, 46(1), 88-99.

Neuliep, J. W., \& McCroskey, J. C. (1997). The development of a US and generalized ethnocentrism scale. Communication Research Reports, 14(4), 385-398.

Neuliep, J. W., \& McCroskey, J. C. (1997). The development of intercultural and interethnic communication apprehension scales. Communication Research Reports, 14(2), 145-156.

Neuliep, J. W., \& McCroskey, J. C. (2001). The influence of ethnocentrism on perceptions of interviewee attractiveness, credibility, and socio-communicative style. In annual convention of the International Communication Association, Washington, DC.

Neuliep, J. W., \& Ryan, D. J. (1998). The influence of intercultural communication apprehension and socio-communicative orientation on uncertainty reduction during initial cross cultural interaction. Communication Quarterly, 46(1), 88-99.
Ng, S. H., \& Bradac, J. J. (1993). Power in language: Verbal communication and social influenc. Sage Publications, Inc.

Ovalle, B. D., \& Chakraborty, R. (2013). Accent Policy and Accent Modification Enterprises as Potential Indicators of Intercultural Power Relations: A Call for an Updated Research Agenda. SIG 17 Perspectives on Global Issues in Communication Sciences and Related Disorders, 3(1), 22-33.

Perreault, S., \& Bourhis, R. Y. (1999). Ethnocentrism, social identification, and discrimination. Personality and Social Psychology Bulletin, 25(1), 92-103.

Perry, S. P., Murphy, M. C., \& Dovidio, J. F. (2015). Modern prejudice: Subtle, but unconscious? The role of Bias Awareness in Whites' perceptions of personal and others' biases. Journal of Experimental Social Psychology, 61, 64-78. DOI: 10.1016/j.jesp.2015.06.007

Phills, C. E., Kawakami, K., Tabi, E., Nadolny, D., \& Inzlicht, M. (2011). Mind the gap: Increasing associations between the self and Blacks with approach behaviors. Journal of personality and social psychology, 100(2), $197-210$.

Rogers, C. L., DeMasi, T. M., \& Krause, J. C. (2010). Conversational and clear speech intelligibility of/bVd/syllables produced by native and non-native English speakers. Journal of the Acoustical Society of America, 128, 410-423.

Ryan, C. (2013). Language use in the United States: 2011. American community survey reports, 22, 1-16.

Rubin, D. L. (1992). Nonlanguage factors affecting undergraduates' judgments of nonnative English-speaking teaching assistants. Research in Higher education, 33(4), 511-531.

Rubin, D. L., \& Smith, K. A. (1990). Effects of accent, ethnicity, and lecture topic on undergraduates' perceptions of nonnative English-speaking teaching assistants. International Journal of Intercultural Relations, 14(3), 337-353.

Shah, A. P. (2012). Accent modification for speakers with Indian accents: Speech characteristics and an assessment framework. SIG 14 Perspectives on Communication Disorders and Sciences in Culturally and Linguistically Diverse (CLD) Populations, 19(1), 12-20.

Smiljanić, R., \& Bradlow, A. R. (2008). Temporal organization of English clear and conversational speech a. The Journal of the Acoustical Society of America, 124(5), 3171-3182.

Sumner, W. G. (1906). Folkways: A study of the sociological importance of usages, manners, customs, mores, and morals. Boston, MA: Ginn and Company.

Tajfel, H. (1972). La catégorisation sociale [Social categorization]. In S. Moscovici (Ed.). Introduction à la psychologie sociale (Vol. 1, pp. 272-302). Paris: Larousse.

Turner, J. C., Brown, R. J., \& Tajfel, H. (1979). Social comparison and group interest in ingroup favouritism. European journal of social psychology, 9(2), 187-204.

Vornik, L., Sharman, S., \& Garry, M. (2003). The power of the spoken word: Sociolinguistic cues influence the misinformation effect. Memory, 11(1), 101-109. 
Warr, P. B., Faust, J., \& Harrison, G. J. (1967). A British ethnocentrism scale. British Journal of Social and Clinical Psychology, 6(4), 267-277.

Weber, J. G. (1994). The nature of ethnocentric attribution bias: Ingroup protection or enhancement?. Journal of
Experimental Social Psychology, 30: 482-504.

Yzerbyt, V., Provost, V., \& Corneille, O. (2005). Not competent but warm. really? Compensatory stereotypes in the French-speaking world. Group Processes \& Intergroup Relations, 8(3), 291-308. 